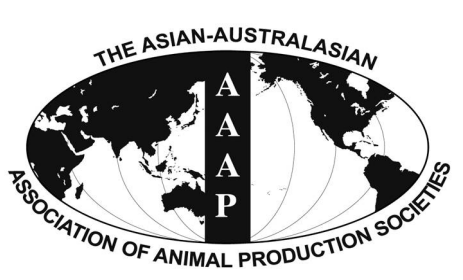

Open Access

Asian Australas. J. Anim. Sci.

Vol. 29, No. 8 : 1145-1151 August 2016

http://dx.doi.org/10.5713/ajas.15.0553

www.ajas.info

pISSN 1011-2367 elSSN 1976-5517

\title{
Evaluation of Relative Bioavailability of 25-Hydroxycholecalciferol to Cholecalciferol for Broiler Chickens
}

\author{
J. C. Han ${ }^{1}{ }^{*}$, G. H. Chen ${ }^{1,2}$, J. G. Wang ${ }^{1,2}$, J. L. Zhang ${ }^{1,2}$, H. X. Qu ${ }^{1}$, C. M. Zhang ${ }^{1}$, Y. F. Yan ${ }^{1}{ }^{*}$, and Y. H. Cheng ${ }^{3}$ \\ ${ }^{1}$ Department of Animal Science, College of Life Science, Shangqiu Normal University, \\ Shangqiu, Henan 476000, China
}

\begin{abstract}
This study was conducted to evaluate the relative bioavailability (RBV) of 25-hydroxycholecalciferol $\left(25-\mathrm{OH}-\mathrm{D}_{3}\right)$ to cholecalciferol (vitamin $\mathrm{D}_{3}$ ) in 1- to 21-d-old broiler chickens fed with calcium (Ca)- and phosphorus (P)-deficient diets. On the day of hatch, 450 female Ross 308 broiler chickens were assigned to nine treatments, with five replicates of ten birds each. The basal diet contained $0.50 \% \mathrm{Ca}$ and $0.25 \%$ non-phytate phosphorus (NPP) and was not supplemented with vitamin D. Vitamin $\mathrm{D}_{3}$ was fed at $0,2.5$, $5.0,10.0$, and $20.0 \mu \mathrm{g} / \mathrm{kg}$, and $25-\mathrm{OH}-\mathrm{D}_{3}$ was fed at $1.25,2.5,5.0$, and $10.0 \mu \mathrm{g} / \mathrm{kg}$. The RBV of $25-\mathrm{OH}-\mathrm{D}_{3}$ was determined using vitamin $\mathrm{D}_{3}$ as the standard source by the slope ratio method. Vitamin $\mathrm{D}_{3}$ and $25-\mathrm{OH}-\mathrm{D}_{3}$ intake was used as the independent variable for regression analysis. The linear relationships between the level of vitamin $\mathrm{D}_{3}$ or $25-\mathrm{OH}-\mathrm{D}_{3}$ and body weight gain (BWG) and the weight, length, ash weight, and the percentage of ash, $\mathrm{Ca}$, and $\mathrm{P}$ in femur, tibia, and metatarsus of broiler chickens were observed. Using BWG as the criterion, the $\mathrm{RBV}$ value of $25-\mathrm{OH}-\mathrm{D}_{3}$ to vitamin $\mathrm{D}_{3}$ was 1.85 . Using the mineralization of the femur, tibia, and metatarsus as criteria, the RBV of $25-\mathrm{OH}-\mathrm{D}_{3}$ to vitamin $\mathrm{D}_{3}$ ranged from 1.82 to $2.45,1.86$ to 2.52 , and 1.65 to 2.05 , respectively. These data indicate that $25-\mathrm{OH}-\mathrm{D}_{3}$ is approximately 2.03 times as active as vitamin $\mathrm{D}_{3}$ in promoting growth performance and bone mineralization in broiler chicken diets. (Key Words: 25-Hydroxycholecalciferol, Cholecalciferol, Relative Bioavailability, Growth, Bone, Broiler Chicken)
\end{abstract}

\section{INTRODUCTION}

Cholecalciferol (vitamin $\mathrm{D}_{3}$ ) has been used as a feed additive to regulate calcium $(\mathrm{Ca})$ and phosphorus $(\mathrm{P})$ metabolism and bone development in animals for many years. Vitamin $\mathrm{D}_{3}$ undergoes 25-hydroxylation in animal livers to transform 25-hydroxycholecalciferol $\left(25-\mathrm{OH}-\mathrm{D}_{3}\right)$. The commercial 25-OH-D 3 has been produced and approved for use in poultry and swine feed in China in 2014.

Previous research has shown that body weight and feed efficiency of broiler chickens fed with $25-\mathrm{OH}-\mathrm{D}_{3}$ were greater than those of the birds fed with vitamin $\mathrm{D}_{3}$ (Yarger

\footnotetext{
* Corresponding Authors: J. C. Han. Tel: +86-0370-2592849, E-mail: j.c.han@hotmail.com / Y. F. Yan. Tel: +86-0370-2594568, E-mail: yanyf01@sina.com

${ }^{2}$ College of Animal Husbandry and Veterinary Science, Henan Agricultural University, Zhengzhou, Henan 450002, China.

${ }^{3}$ Department of Biotechnology and Animal Science, National Ilan University, I-Lan 26047, Taiwan.

Submitted Jul. 2, 2015; Revised Aug. 25, 2015; Accepted Oct. 14, 2015
}

et al., 1995; Fritts and Waldroup, 2003). Replacing vitamin $\mathrm{D}_{3}$ by $25-\mathrm{OH}-\mathrm{D}_{3}$ at $50 \%$ has a beneficial effect on the growth performance of broilers (Koreleski and Swiatkiewicz, 2005). These data indicate that the relative bioavailability (RBV) of $25-\mathrm{OH}-\mathrm{D}_{3}$ is higher than that of vitamin $\mathrm{D}_{3}$.

However, no consistent results have been obtained in the RBV of $25-\mathrm{OH}-\mathrm{D}_{3}$ to vitamin $\mathrm{D}_{3}$. Soares et al. (1995) reviewed that the RBV of $25-\mathrm{OH}-\mathrm{D}_{3}$ to vitamin $\mathrm{D}_{3}$ ranged from 1.0 to 4.0 when $\mathrm{Ca}$ absorption, plasma $\mathrm{Ca}$, bone ash, bone strength, and tibial dyschondroplasia were used as the criteria. Atencio et al. (2005) found that the RBV values of $25-\mathrm{OH}-\mathrm{D}_{3}$ to vitamin $\mathrm{D}_{3}$ were $1.38,1.33,1.28$, and 1.11 for egg production, hatchability, late embryo mortality, and body ash of the progeny in broiler breeder hen diets, respectively. These data reveal the differences in the RBV of $25-\mathrm{OH}-\mathrm{D}_{3}$ to vitamin $\mathrm{D}_{3}$ among the studies. The RBV of 25-OH- $\mathrm{D}_{3}$ to vitamin $\mathrm{D}_{3}$ in poultry diets should be further clarified.

Researchers usually use the tibia to evaluate the RBV of 
vitamin D derivatives. In fact, the differences in growth and mineralization among the femur, tibia, and metatarsus in poultry have been observed (Applegate and Lilburn, 2002; Goetting-Fuchs et al., 2012; Han et al., 2015). The femur and metatarsus should also be used as criteria to evaluate the RBV of 25-OH-D 3 to vitamin $\mathrm{D}_{3}$.

Therefore, the present study was conducted to investigate the effects of $25-\mathrm{OH}-\mathrm{D}_{3}$ and vitamin $\mathrm{D}_{3}$ on the growth performance and development of the femur, tibia, and metatarsus and to re-evaluate the RBV of $25-\mathrm{OH}-\mathrm{D}_{3}$ to vitamin $\mathrm{D}_{3}$ in broilers fed with $\mathrm{Ca}$ - and $\mathrm{P}$-deficient diets.

\section{MATERIALS AND METHODS}

\section{Birds, diets, and management}

All of the procedures adopted in this study were approved by the Animal Care Committee of Shangqiu Normal University.

On the day of hatch, 450 female Ross 308 broiler chickens were assigned to nine treatments, with five replicates of ten birds each. The initial body weight of broiler chickens was $46.5 \pm 1.9 \mathrm{~g}$. Birds from 1 to $13 \mathrm{~d}$ of age were reared in stainless steel starter cages $(70 \mathrm{~cm} \times 70$ $\mathrm{cm} \times 30 \mathrm{~cm})$. At $14 \mathrm{~d}$, the broilers were transferred to stainless steel grower cages $(190 \mathrm{~cm} \times 50 \mathrm{~cm} \times 35 \mathrm{~cm})$. The basal diet contained $0.50 \% \mathrm{Ca}$ and $0.25 \%$ non-phytate phosphorus (NPP) and was not supplemented with vitamin D. Vitamin $\mathrm{D}_{3}$ was fed at $0,2.5,5.0,10.0$, and $20.0 \mu \mathrm{g} / \mathrm{kg}$ and $25-\mathrm{OH}-\mathrm{D}_{3}$ was fed at $1.25,2.5,5.0$, and $10.0 \mu \mathrm{g} / \mathrm{kg}$. The birds were provided mash diet (Table 1) and water $a d$ libitum. The lighting system consisted of $23 \mathrm{~h}$ of light from $1 \mathrm{~d}$ to $3 \mathrm{~d}$ and $20 \mathrm{~h}$ of light from $4 \mathrm{~d}$ to $21 \mathrm{~d}$. Room temperature was controlled at $33^{\circ} \mathrm{C}$ from $0 \mathrm{~d}$ to $3 \mathrm{~d}, 30^{\circ} \mathrm{C}$ from $4 \mathrm{~d}$ to $7 \mathrm{~d}, 27^{\circ} \mathrm{C}$ from $8 \mathrm{~d}$ to $14 \mathrm{~d}$, and $24^{\circ} \mathrm{C}$ from $15 \mathrm{~d}$ to $21 \mathrm{~d}$.

\section{5-OH- $\mathrm{D}_{3}$ and vitamin $\mathrm{D}_{3}$}

Crystalline 25-OH-D $(98 \%)$ and vitamin $\mathrm{D}_{3}(99 \%)$ were supplied by Changzhou Book Chemical Co., Ltd. (Changzhou, China) and Jiaxing Tianhecheng Biological Technology Co., Ltd. (Jiaxing, China), respectively. The 25$\mathrm{OH}-\mathrm{D}_{3}$ and vitamin $\mathrm{D}_{3}$ solutions were prepared by the method of Biehl and Baker (1997). Crystalline 25-OH-D and vitamin $\mathrm{D}_{3}$ were weighed and dissolved in ethanol. Then, they were diluted to a final concentration of $10 \mathrm{mg} / \mathrm{L}$ of $25-\mathrm{OH}-\mathrm{D}_{3}$ or vitamin $\mathrm{D}_{3}$ in a solution of $5 \%$ ethanol and $95 \%$ propylene glycol. After the preparation, the solution of $25-\mathrm{OH}-\mathrm{D}_{3}$ or vitamin $\mathrm{D}_{3}$ was added to the diets.

\section{Sample collection}

The birds were weighed on d 21 after $12 \mathrm{~h}$ of fasting. Ten chicks per treatment were randomly selected for the collection of blood, femur, tibia, and metatarsus. Plasma
Table 1. Ingredients and nutrient composition of the basal diet

\begin{tabular}{lc}
\hline Items & Basal diet \\
\hline Ingredient (\%) & 60.73 \\
Corn & 32.00 \\
Soya bean meal (43\% CP) & 1.60 \\
Soya bean oil & 3.47 \\
Soya bean protein isolate (65\% CP) & 0.67 \\
Limestone & 0.71 \\
Dicalcium phosphate & 0.14 \\
L-lysine·HCl $(98 \%)$ & 0.14 \\
DL-methionine $(98 \%)$ & 0.01 \\
Trace mineral premix ${ }^{1}$ & 0.03 \\
Vitamin premix ${ }^{2}$ & 0.20 \\
Choline chloride (50\%) & 0.30 \\
Sodium chloride & \\
Nutrient composition & $2,975.20$ \\
Metabolizable energy (kcal/kg) & 21.24 \\
Crude protein $(\mathrm{CP}, \%)$ & 0.52 \\
Analyzed calcium $(\mathrm{Ca}, \%)$ & 0.49 \\
Analyzed total phosphorus (TP, \%) & 0.25 \\
Non-phytate phosphorus (NPP, \%)
\end{tabular}

${ }^{1}$ The trace mineral premix provided the following (per kg of diet): $80 \mathrm{mg}$ iron; $40 \mathrm{mg}$ zinc; $8 \mathrm{mg}$ copper; $60 \mathrm{mg}$ manganese; $0.35 \mathrm{mg}$ iodine; and $0.15 \mathrm{mg}$ selenium.

${ }^{2}$ The vitamin premix provided the following (per $\mathrm{kg}$ of diet): $8,000 \mathrm{IU}$ vitamin A; $20 \mathrm{IU}$ vitamin $\mathrm{E} ; 0.5 \mathrm{mg}$ menadione; $2.0 \mathrm{mg}$ thiamine; $8.0 \mathrm{mg}$ riboflavin; $35 \mathrm{mg}$ niacin; $3.5 \mathrm{mg}$ pyridoxine; $0.01 \mathrm{mg}$ vitamin $\mathrm{B}_{12} ; 10.0$ $\mathrm{mg}$ pantothenic acid; $0.55 \mathrm{mg}$ folic acid; and $0.18 \mathrm{mg}$ biotin.

samples $(5 \mathrm{~mL})$ were collected through cardiac puncture and centrifuged for $10 \mathrm{~min}$ at $3,000 \times \mathrm{g}$ at $20^{\circ} \mathrm{C}$. The birds were killed after collecting the blood samples. The femur, tibia, and metatarsus of the individual birds were excised and frozen at $-20^{\circ} \mathrm{C}$ for analysis.

\section{Sample analysis}

Plasma $\mathrm{Ca}$ and inorganic phosphorus (Pi) were determined using a Shimadzu CL-8000 analyzer (Shimadzu Corp., Kyoto, Japan) following the instructions of the manufacturer.

The left femur, tibia, and metatarsus were boiled for 5 min to loosen the muscle tissues using the method of Hall et al. (2003). The meat, connective tissue, and fibula bone were completely removed using scissors and forceps. The bones were placed in a container of ethanol for $24 \mathrm{~h}$ (removing water and polar lipids) after cleaning. Afterward, the bones were further extracted in anhydrous ether for $24 \mathrm{~h}$ (removing non-polar lipids). The bones were dried at $105^{\circ} \mathrm{C}$ for $24 \mathrm{~h}$ before weighing. The bone ash content was determined by ashing the bone in a muffle furnace for $48 \mathrm{~h}$ at $600^{\circ} \mathrm{C}$.

The right tibia was utilized to analyze the breakingstrength, which was determined using an all-digital electronic universal testing machine (Shenzhen Hengen Instrument Co. Ltd., Shenzhen, China). The tibias were 
cradled on two support points measuring $4 \mathrm{~cm}$ apart. Force was applied to the midpoint of the same face of each tibia using a $50 \mathrm{~kg}$ load cell with a crosshead speed of 10 $\mathrm{mm} / \mathrm{min}$ (Jendral et al., 2008).

Dietary and bone $\mathrm{Ca}$ were determined by the ethylene diamine tetraacetic acid titration method, and $\mathrm{P}$ was determined by photometric methods after reaction with ammonium molybdate and ammonium metavanadate (Han et al., 2013).

\section{Statistical analysis}

Replicate means are the experimental units in the statistical analysis. Data were analyzed with a general linear model of the SAS software (SAS Institute, 2002). The RBV of $25-\mathrm{OH}-\mathrm{D}_{3}$ was determined using vitamin $\mathrm{D}_{3}$ as the standard source by the slope ratio method (Littell et al., 1997). Feed intake differed for the dietary treatments so that vitamin $\mathrm{D}$ intake rather than vitamin $\mathrm{D}$ content was used as the independent variable for regression analysis. The model is as follows: $y=a+b_{1} x_{1}+b_{2} x_{2}$, where $y$ is the response, $x_{1}$ is vitamin $\mathrm{D}_{3}$ intake, $x_{2}$ is $25-\mathrm{OH}-\mathrm{D}_{3}$ intake, $a$ is the intercept, and $b_{1}$ and $b_{2}$ are the slope of vitamin $\mathrm{D}_{3}$ and $25-\mathrm{OH}-\mathrm{D}_{3}$, respectively. Orthogonal comparisons were performed to determine the linear and quadratic effects of the 25-OH- $\mathrm{D}_{3}$ or vitamin $\mathrm{D}_{3}$ levels on growth performance and bone mineralization. The basal diet treatment was included for both vitamin $\mathrm{D}_{3}$ and $25-\mathrm{OH}-\mathrm{D}_{3}$ when conducting orthogonal polynomial contrast test. Means were compared by conducting Tukey test when probability values were significant $(\mathrm{p}<0.05)$.

\section{RESULTS}

\section{Growth performance}

Dietary $25-\mathrm{OH}-\mathrm{D}_{3}$ linearly affected body weight gain (BWG), feed intake (FI), feed efficiency, and mortality in 1to 21-d-old broiler chickens ( $\mathrm{p}<0.05$, Table 2). Vitamin $\mathrm{D}_{3}$ levels also influenced the above parameters $(p<0.05)$. 25$\mathrm{OH}-\mathrm{D}_{3}$ or vitamin $\mathrm{D}_{3}$ did not affect the plasma $\mathrm{Ca}$ or $\mathrm{Pi}$ concentration $(\mathrm{p}>0.05)$.

\section{Bone mineralization}

The femur, tibia, and metatarsus are three leg bones in poultry. They reflect the body bone quality of birds. The linear relationships between the level of $25-\mathrm{OH}-\mathrm{D}_{3}$ or vitamin $\mathrm{D}_{3}$ and the weight, length, ash weight, and the percentage of ash, $\mathrm{Ca}$, and $\mathrm{P}$ of the femur in broiler chickens were observed $(p<0.05$, Table 3$)$.

Dietary $25-\mathrm{OH}-\mathrm{D}_{3}$ or vitamin $\mathrm{D}_{3}$ linearly improved the tibia breaking-strength $(\mathrm{p}<0.05$, Table 4$)$. Similar results were observed in the relationship between the level of 25 $\mathrm{OH}-\mathrm{D}_{3}$ or vitamin $\mathrm{D}_{3}$ and the weight, length, ash weight, and the percentage of ash, $\mathrm{Ca}$, and $\mathrm{P}$ of the tibia.

Increasing the $25-\mathrm{OH}-\mathrm{D}_{3}$ or vitamin $\mathrm{D}_{3}$ level linearly increased the weight, length, ash weight, and the percentage of ash, $\mathrm{Ca}$, and $\mathrm{P}$ of the metatarsus $(\mathrm{p}<0.05$, Table 5).

\section{Relative bioavailability of $25-\mathrm{OH}-\mathrm{D}_{\mathbf{3}}$ to vitamin $\mathrm{D}_{\mathbf{3}}$}

The slope ratio method was used to evaluate the RBV of 25-OH- $\mathrm{D}_{3}$ to vitamin $\mathrm{D}_{3}$ in broiler chickens (Table 6). Vitamin $\mathrm{D}_{3}$ and 25-OH- $\mathrm{D}_{3}$ intake was used as the independent variable for regression analysis. The slopes of

Table 2. Effects of vitamin $\mathrm{D}_{3}$ and $25-\mathrm{OH}-\mathrm{D}_{3}$ on growth performance and plasma mineral concentration in 1- to 21-d-old broiler chickens

\begin{tabular}{|c|c|c|c|c|c|c|c|}
\hline \multirow{2}{*}{$\begin{array}{c}\text { Vitamin } D_{3} \\
(\mu \mathrm{g} / \mathrm{kg})\end{array}$} & \multirow{2}{*}{$\begin{array}{c}25-\mathrm{OH}-\mathrm{D}_{3} \\
(\mu \mathrm{g} / \mathrm{kg})\end{array}$} & \multicolumn{4}{|c|}{ Growth } & \multicolumn{2}{|c|}{ Plasma } \\
\hline & & BWG (g/bird) & FI (g/bird) & $\mathrm{FE}(\mathrm{BWG} / \mathrm{FI})$ & Mortality (\%) & $\mathrm{Ca}(\mathrm{mg} / \mathrm{dL})$ & $\mathrm{Pi}(\mathrm{mg} / \mathrm{dL})$ \\
\hline 0 & 0 & $233^{d}$ & $431^{d}$ & $0.542^{\mathrm{c}}$ & $26^{\mathrm{a}}$ & 5.45 & 3.07 \\
\hline 2.5 & & $338^{\mathrm{c}}$ & $621^{\mathrm{bc}}$ & $0.548^{\mathrm{bc}}$ & $12^{\mathrm{b}}$ & 6.69 & 3.27 \\
\hline 5.0 & & $433^{b}$ & $709^{b}$ & $0.612^{\mathrm{a}}$ & $0^{\mathrm{b}}$ & 6.90 & 3.83 \\
\hline 10.0 & & $584^{\mathrm{a}}$ & $932^{\mathrm{a}}$ & $0.627^{\mathrm{a}}$ & $0^{\mathrm{b}}$ & 6.93 & 4.82 \\
\hline \multirow[t]{5}{*}{20.0} & & $602^{\mathrm{a}}$ & $955^{\mathrm{a}}$ & $0.631^{\mathrm{a}}$ & $0^{\mathrm{b}}$ & 6.98 & 4.64 \\
\hline & 1.25 & $321^{\mathrm{c}}$ & $585^{\mathrm{c}}$ & $0.549^{b c}$ & $10^{\mathrm{b}}$ & 5.72 & 3.24 \\
\hline & 2.5 & $426^{\mathrm{b}}$ & $702^{b}$ & $0.606^{\mathrm{ab}}$ & $0^{\mathrm{b}}$ & 5.70 & 3.60 \\
\hline & 5.0 & $556^{\mathrm{a}}$ & $866^{\mathrm{a}}$ & $0.642^{\mathrm{a}}$ & $0^{\mathrm{b}}$ & 6.70 & 3.66 \\
\hline & 10.0 & $574^{\mathrm{a}}$ & $927^{\mathrm{a}}$ & $0.619^{\mathrm{a}}$ & $0^{\mathrm{b}}$ & 6.73 & 4.17 \\
\hline SEM & & 19 & 27 & 0.007 & 2 & 0.16 & 0.18 \\
\hline \multicolumn{8}{|l|}{$\mathrm{p}$ value } \\
\hline \multirow[t]{2}{*}{ Vitamin $D_{3}$} & Linear & $<0.001$ & $<0.001$ & $<0.001$ & $<0.001$ & 0.043 & 0.022 \\
\hline & Quadratic & 0.002 & 0.006 & 0.363 & 0.010 & 0.171 & 0.890 \\
\hline \multirow[t]{2}{*}{$25-\mathrm{OH}-\mathrm{D}_{3}$} & Linear & $<0.001$ & $<0.001$ & $<0.001$ & $<0.001$ & 0.013 & 0.038 \\
\hline & Quadratic & 0.036 & 0.089 & 0.067 & $<0.001$ & 0.732 & 0.797 \\
\hline
\end{tabular}

25-OH-D 3 , 25-hydroxycholecalciferol; BWG, body weight gain; FI, feed intake; FE, feed efficiency; Ca, calcium; Pi, inorganic phosphorus; SEM, standard error of the mean.

${ }^{\mathrm{a}-\mathrm{d}}$ Means in the same column without a common superscript differ significantly $(\mathrm{p}<0.05)$. 
Table 3. Effects of vitamin $\mathrm{D}_{3}$ and 25-OH- $\mathrm{D}_{3}$ on femur mineralization in 1- to 21-d-old broiler chickens

\begin{tabular}{|c|c|c|c|c|c|c|c|}
\hline$\overline{\text { Vitamin } D_{3}(\mu \mathrm{g} / \mathrm{kg})}$ & $25-\mathrm{OH}-\mathrm{D}_{3}(\mu \mathrm{g} / \mathrm{kg})$ & Weight $(\mathrm{g})$ & Length $(\mathrm{cm})$ & Ash (g) & Ash (\%) & $\mathrm{Ca}(\%)$ & $\mathrm{P}(\%)$ \\
\hline 0 & 0 & $0.56^{\mathrm{d}}$ & $3.43^{\mathrm{f}}$ & $0.17^{\mathrm{d}}$ & $26.64^{\mathrm{e}}$ & $10.30^{\mathrm{e}}$ & $4.92^{\mathrm{f}}$ \\
\hline 2.5 & & $0.63^{\mathrm{cd}}$ & $3.75^{\mathrm{ef}}$ & $0.20^{\mathrm{d}}$ & $33.89^{\mathrm{cd}}$ & $12.70^{\mathrm{cd}}$ & $6.04^{\mathrm{de}}$ \\
\hline 5.0 & & $0.78^{\mathrm{b}}$ & $4.34^{\mathrm{bcd}}$ & $0.29^{\mathrm{c}}$ & $37.55^{\mathrm{bc}}$ & $13.01^{\mathrm{cd}}$ & $6.78^{\text {cde }}$ \\
\hline 10.0 & & $1.01^{\mathrm{a}}$ & $4.69^{\mathrm{ab}}$ & $0.40^{\mathrm{ab}}$ & $39.55^{\mathrm{b}}$ & $14.02^{\mathrm{abc}}$ & $7.13^{\mathrm{bc}}$ \\
\hline \multirow[t]{5}{*}{20.0} & & $1.07^{\mathrm{a}}$ & $4.87^{\mathrm{a}}$ & $0.45^{\mathrm{a}}$ & $43.71^{\mathrm{a}}$ & $15.20^{\mathrm{ab}}$ & $7.88^{\mathrm{ab}}$ \\
\hline & 1.25 & $0.69^{\mathrm{bc}}$ & $3.85^{\mathrm{def}}$ & $0.23^{\mathrm{cd}}$ & $33.07^{\mathrm{d}}$ & $11.31^{\mathrm{de}}$ & $5.91^{\mathrm{e}}$ \\
\hline & 2.5 & $0.80^{\mathrm{b}}$ & $4.10^{\text {cde }}$ & $0.29^{\mathrm{c}}$ & $36.37^{\mathrm{bcd}}$ & $13.48^{\mathrm{bc}}$ & $6.68^{\text {cde }}$ \\
\hline & 5.0 & $0.98^{\mathrm{a}}$ & $4.58^{\mathrm{abc}}$ & $0.38^{\mathrm{b}}$ & $38.64^{\mathrm{b}}$ & $14.52^{\mathrm{abc}}$ & $6.95^{\mathrm{cd}}$ \\
\hline & 10.0 & $1.02^{\mathrm{a}}$ & $4.77^{\mathrm{ab}}$ & $0.45^{\mathrm{a}}$ & $44.14^{\mathrm{a}}$ & $15.86^{\mathrm{a}}$ & $8.22^{\mathrm{a}}$ \\
\hline SEM & & 0.03 & 0.08 & 0.02 & 0.81 & 0.28 & 0.16 \\
\hline \multicolumn{8}{|l|}{$p$ value } \\
\hline \multirow[t]{2}{*}{ Vitamin $D_{3}$} & Linear & $<0.001$ & $<0.001$ & $<0.001$ & $<0.001$ & $<0.001$ & $<0.001$ \\
\hline & Quadratic & 0.352 & 0.268 & 0.288 & 0.033 & 0.318 & 0.207 \\
\hline \multirow[t]{2}{*}{$25-\mathrm{OH}-\mathrm{D}_{3}$} & Linear & $<0.001$ & $<0.001$ & $<0.001$ & $<0.001$ & $<0.001$ & $<0.001$ \\
\hline & Quadratic & 0.424 & 0.590 & 0.457 & 0.368 & 0.761 & 0.936 \\
\hline
\end{tabular}

25-OH-D 3 , 25-hydroxycholecalciferol; SEM, standard error of the mean.

${ }^{\mathrm{a}-\mathrm{f}}$ Means in the same column without a common superscript differ significantly $(\mathrm{p}<0.05)$.

vitamin $\mathrm{D}_{3}$ and $25-\mathrm{OH}-\mathrm{D}_{3}$ were 16.706 and 30.862 , respectively, when BWG was used as the criterion. Thus, the $\mathrm{RBV}$ value of $25-\mathrm{OH}-\mathrm{D}_{3}$ to vitamin $\mathrm{D}_{3}$ was 1.85 (namely 185\%, 30.862 divided by 16.706).

Using BWG as the criterion, the RBV value of $25-\mathrm{OH}-$ $\mathrm{D}_{3}$ to vitamin $\mathrm{D}_{3}$ was 1.85 . When the weight, length, ash weight, and the percentage of ash, $\mathrm{Ca}$, and $\mathrm{P}$ of the femur were used as the criteria, the RBV of $25-\mathrm{OH}-\mathrm{D}_{3}$ to vitamin $\mathrm{D}_{3}$ were $1.88,1.82,2.00,2.03,2.45$, and 2.22 , respectively. Using the same parameters of the tibia as the criteria, the $\mathrm{RBV}$ of $25-\mathrm{OH}-\mathrm{D}_{3}$ to vitamin $\mathrm{D}_{3}$ were $2.12,1.86,2.17,2.13$, 2.52 , and 2.52, respectively. Metatarsus mineralization was also used as a criterion. The above RBV values were 2.05 , $1.89,2.00,1.76,1.73$, and 1.65 , respectively.
Generally, the bioavailability of $25-\mathrm{OH}-\mathrm{D}_{3}$ is higher than that of vitamin $\mathrm{D}_{3}$ in broilers. The average RBV of 25 OH- $\mathrm{D}_{3}$ to vitamin $\mathrm{D}_{3}$ is approximately 2.03 (namely 203\%) in promoting growth performance and bone mineralization in 1- to 21-d-old broiler chicken diets.

\section{DISCUSSION}

Previous research has shown that vitamin $\mathrm{D}_{3}$ levels linearly improve growth and bone quality when broilers are fed with Ca- and NPP-deficient diets; by contrast, growth is quadratically or not significantly affected by vitamin $\mathrm{D}_{3}$ levels when the $\mathrm{Ca}$ and NPP contents are sufficient (Aburto et al., 1998; Baker et al., 1998; Rao et al., 2009). Thus, the

Table 4. Effects of vitamin $\mathrm{D}_{3}$ and $25-\mathrm{OH}-\mathrm{D}_{3}$ on tibia mineralization in 1 - to 21 -d-old broiler chickens

\begin{tabular}{|c|c|c|c|c|c|c|c|c|}
\hline Vitamin $\mathrm{D}_{3}(\mu \mathrm{g} / \mathrm{kg})$ & $25-\mathrm{OH}-\mathrm{D}_{3}(\mu \mathrm{g} / \mathrm{kg})$ & $\mathrm{BS}(\mathrm{N})$ & Weight (g) & Length $(\mathrm{cm})$ & $\operatorname{Ash}(g)$ & Ash (\%) & $\mathrm{Ca}(\%)$ & $\mathrm{P}(\%)$ \\
\hline 0 & 0 & $20.28^{\mathrm{d}}$ & $0.66^{\mathrm{d}}$ & $4.71^{d}$ & $0.18^{\mathrm{e}}$ & $26.82^{f}$ & $9.76^{\mathrm{e}}$ & $5.08^{d}$ \\
\hline 2.5 & & $24.94^{\mathrm{d}}$ & $0.80^{\mathrm{d}}$ & $5.26^{\mathrm{c}}$ & $0.26^{\mathrm{d}}$ & $32.70^{\text {de }}$ & $11.51^{\mathrm{d}}$ & $6.00^{\mathrm{cd}}$ \\
\hline 5.0 & & $39.87^{\mathrm{c}}$ & $1.01^{\mathrm{bc}}$ & $5.71^{\mathrm{bc}}$ & $0.37^{\mathrm{c}}$ & $36.70^{\mathrm{cd}}$ & $13.18^{\mathrm{bc}}$ & $6.83^{b c}$ \\
\hline 10.0 & & $54.10^{\mathrm{b}}$ & $1.32^{\mathrm{a}}$ & $6.23^{\mathrm{a}}$ & $0.51^{b}$ & $39.61^{\mathrm{abc}}$ & $13.81^{\mathrm{bc}}$ & $7.14^{\mathrm{ab}}$ \\
\hline \multirow[t]{5}{*}{20.0} & & $68.91^{\mathrm{a}}$ & $1.38^{\mathrm{a}}$ & $6.38^{\mathrm{a}}$ & $0.57^{\mathrm{ab}}$ & $41.65^{\mathrm{ab}}$ & $14.13^{\mathrm{ab}}$ & $7.15^{\mathrm{ab}}$ \\
\hline & 1.25 & $21.51^{\mathrm{d}}$ & $0.83^{\mathrm{cd}}$ & $5.38^{\mathrm{c}}$ & $0.26^{\mathrm{d}}$ & $31.81^{\mathrm{e}}$ & $11.23^{\mathrm{de}}$ & $5.53^{d}$ \\
\hline & 2.5 & $39.83^{c}$ & $1.06^{\mathrm{b}}$ & $5.52^{\mathrm{c}}$ & $0.39^{\mathrm{c}}$ & $36.88^{\mathrm{cd}}$ & $12.44^{\mathrm{cd}}$ & $6.77^{\mathrm{bc}}$ \\
\hline & 5.0 & $49.32^{b c}$ & $1.32^{\mathrm{a}}$ & $6.12^{\mathrm{ab}}$ & $0.50^{\mathrm{b}}$ & $37.76^{b c}$ & $13.14^{b c}$ & $6.91^{\mathrm{abc}}$ \\
\hline & 10.0 & $71.18^{\mathrm{a}}$ & $1.39^{\mathrm{a}}$ & $6.30^{\mathrm{a}}$ & $0.59^{\mathrm{a}}$ & $42.93^{\mathrm{a}}$ & $15.59^{\mathrm{a}}$ & $7.77^{\mathrm{a}}$ \\
\hline SEM & & 2.88 & 0.04 & 0.09 & 0.02 & 0.78 & 0.27 & 0.14 \\
\hline \multicolumn{9}{|l|}{$\mathrm{p}$ value } \\
\hline \multirow[t]{2}{*}{ Vitamin $\mathrm{D}_{3}$} & Linear & $<0.001$ & $<0.001$ & $<0.001$ & $<0.001$ & $<0.001$ & $<0.001$ & $<0.001$ \\
\hline & Quadratic & 0.088 & 0.633 & 0.125 & 0.765 & 0.059 & 0.003 & 0.015 \\
\hline \multirow[t]{2}{*}{$25-\mathrm{OH}-\mathrm{D}_{3}$} & Linear & $<0.001$ & $<0.001$ & $<0.001$ & $<0.001$ & $<0.001$ & $<0.001$ & $<0.001$ \\
\hline & Quadratic & 0.009 & 0.282 & 0.195 & 0.581 & 0.269 & 0.288 & 0.715 \\
\hline
\end{tabular}

25-OH-D 3 , 25-hydroxycholecalciferol; BS, breaking-strength; SEM, standard error of the mean.

${ }^{\mathrm{a}-\mathrm{f}}$ Means in the same column without a common superscript differ significantly $(\mathrm{p}<0.05)$. 
Table 5. Effects of vitamin $\mathrm{D}_{3}$ and 25-OH- $\mathrm{D}_{3}$ on metatarsus mineralization in 1- to 21-d-old broiler chickens

\begin{tabular}{|c|c|c|c|c|c|c|c|}
\hline$\overline{\text { Vitamin } D_{3}(\mu \mathrm{g} / \mathrm{kg})}$ & $25-\mathrm{OH}-\mathrm{D}_{3}(\mu \mathrm{g} / \mathrm{kg})$ & Weight $(\mathrm{g})$ & Length $(\mathrm{cm})$ & Ash (g) & Ash (\%) & $\mathrm{Ca}(\%)$ & $\mathrm{P}(\%)$ \\
\hline 0 & 0 & $0.50^{\mathrm{c}}$ & $3.56^{\mathrm{f}}$ & $0.12^{\mathrm{c}}$ & $22.20^{\mathrm{e}}$ & $7.68^{\mathrm{e}}$ & $3.67^{\mathrm{f}}$ \\
\hline 2.5 & & $0.58^{\mathrm{c}}$ & $3.84^{\mathrm{ef}}$ & $0.17^{\mathrm{c}}$ & $29.02^{\text {cd }}$ & $10.23^{\mathrm{d}}$ & $4.94^{\mathrm{de}}$ \\
\hline 5.0 & & $0.80^{\mathrm{b}}$ & $4.29^{b c}$ & $0.25^{\mathrm{b}}$ & $31.69^{\mathrm{bcd}}$ & $11.77^{\mathrm{bc}}$ & $5.81^{\mathrm{abcd}}$ \\
\hline 10.0 & & $0.91^{\mathrm{ab}}$ & $4.61^{\mathrm{ab}}$ & $0.30^{\mathrm{ab}}$ & $33.06^{\mathrm{abc}}$ & $12.01^{\mathrm{abc}}$ & $5.93^{\mathrm{abc}}$ \\
\hline \multirow[t]{5}{*}{20.0} & & $0.97^{\mathrm{a}}$ & $4.65^{\mathrm{a}}$ & $0.35^{\mathrm{a}}$ & $36.71^{\mathrm{a}}$ & $13.20^{\mathrm{a}}$ & $6.68^{\mathrm{a}}$ \\
\hline & 1.25 & $0.59^{\mathrm{c}}$ & $3.92^{\mathrm{de}}$ & $0.16^{\mathrm{c}}$ & $27.41^{\mathrm{d}}$ & $10.39^{\mathrm{d}}$ & $4.92^{\mathrm{e}}$ \\
\hline & 2.5 & $0.80^{\mathrm{b}}$ & $4.23^{\mathrm{cd}}$ & $0.25^{\mathrm{b}}$ & $29.50^{\mathrm{cd}}$ & $10.84^{\mathrm{cd}}$ & $5.40^{\text {cde }}$ \\
\hline & 5.0 & $0.94^{\mathrm{ab}}$ & $4.55^{\mathrm{abc}}$ & $0.30^{\mathrm{ab}}$ & $31.65^{\mathrm{bcd}}$ & $11.32^{\mathrm{cd}}$ & $5.67^{\text {bcde }}$ \\
\hline & 10.0 & $0.94^{\mathrm{ab}}$ & $4.58^{\mathrm{abc}}$ & $0.34^{\mathrm{a}}$ & $35.86^{\mathrm{ab}}$ & $12.88^{\mathrm{ab}}$ & $6.35^{\mathrm{ab}}$ \\
\hline SEM & & 0.03 & 0.06 & 0.01 & 0.69 & 0.25 & 0.14 \\
\hline \multicolumn{8}{|l|}{$p$ value } \\
\hline \multirow[t]{2}{*}{ Vitamin $D_{3}$} & Linear & $<0.001$ & $<0.001$ & $<0.001$ & $<0.001$ & $<0.001$ & $<0.001$ \\
\hline & Quadratic & 0.133 & 0.052 & 0.582 & 0.029 & $<0.001$ & 0.007 \\
\hline \multirow[t]{2}{*}{$25-\mathrm{OH}-\mathrm{D}_{3}$} & Linear & $<0.001$ & $<0.001$ & $<0.001$ & $<0.001$ & $<0.001$ & $<0.001$ \\
\hline & Quadratic & 0.071 & 0.024 & 0.519 & 0.593 & 0.076 & 0.104 \\
\hline
\end{tabular}

25-OH-D 3 , 25-hydroxycholecalciferol; SEM, standard error of the mean.

${ }^{\mathrm{a}-\mathrm{f}}$ Means in the same column without a common superscript differ significantly $(\mathrm{p}<0.05)$.

Ca- and NPP-deficient diet was designed in the present study. The optimal dietary Ca to NPP ratio is 2.0 to promote growth performance and bone mineralization in broiler chickens (Bar et al., 2003; Rao et al., 2007). Therefore, the $\mathrm{Ca}$ and NPP levels were $0.50 \%$ and $0.25 \%$, respectively.

In the comparison of $25-\mathrm{OH}-\mathrm{D}_{3}$ to vitamin $\mathrm{D}_{3}$ at the
$3.125 \mu \mathrm{g} / \mathrm{kg}$ level, the RBV of $25-\mathrm{OH}-\mathrm{D}_{3}$ to vitamin $\mathrm{D}_{3}$ ranged from 1.08 to 4.00 in broiler breeder hens (Atencio et al., 2005). However, no statistical differences in the performance between $25-\mathrm{OH}-\mathrm{D}_{3}$ and vitamin $\mathrm{D}_{3}$ were observed when their level reached $12.5 \mu \mathrm{g} / \mathrm{kg}$ in hens (Atencio et al., 2005) or $50 \mu \mathrm{g} / \mathrm{kg}$ in broiler chickens (Fritts

Table 6. Relative bioavailability (RBV) of $25-\mathrm{OH}-\mathrm{D}_{3}$ to vitamin $\mathrm{D}_{3}$ based on vitamin $\mathrm{D}$ intake ( $\left.\mu \mathrm{g} / \mathrm{bird}\right)$ in 1- to 21-d-old broiler chickens with the slope ratio method

\begin{tabular}{|c|c|c|c|c|c|c|}
\hline \multirow{2}{*}{ Criteria } & \multirow{2}{*}{ Intercept } & \multicolumn{2}{|c|}{ Slope \pm SE } & \multirow{2}{*}{$\mathrm{p}$ value } & \multirow{2}{*}{$\mathrm{R}^{2}$} & \multirow{2}{*}{$\mathrm{RBV} \pm \mathrm{SE}$} \\
\hline & & Vitamin $\mathrm{D}_{3}$ & $25-\mathrm{OH}-\mathrm{D}_{3}$ & & & \\
\hline \multicolumn{7}{|l|}{ Growth performance } \\
\hline Weight gain & 334.545 & $16.706 \pm 1.799$ & $30.862 \pm 3.726$ & $<0.001$ & 0.73 & $1.85 \pm 0.23$ \\
\hline \multicolumn{7}{|c|}{ Femur mineralization } \\
\hline Weight & 0.666 & $0.024 \pm 0.003$ & $0.045 \pm 0.005$ & $<0.001$ & 0.73 & $1.88 \pm 0.24$ \\
\hline Length & 3.813 & $0.065 \pm 0.008$ & $0.118 \pm 0.017$ & $<0.001$ & 0.66 & $1.82 \pm 0.29$ \\
\hline Ash weight & 0.216 & $0.014 \pm 0.001$ & $0.028 \pm 0.003$ & $<0.001$ & 0.81 & $2.00 \pm 0.20$ \\
\hline Ash percentage & 32.147 & $0.669 \pm 0.075$ & $1.356 \pm 0.156$ & $<0.001$ & 0.73 & $2.03 \pm 0.21$ \\
\hline Ca percentage & 11.776 & $0.198 \pm 0.030$ & $0.485 \pm 0.061$ & $<0.001$ & 0.66 & $2.45 \pm 0.41$ \\
\hline$P$ percentage & 5.797 & $0.121 \pm 0.015$ & $0.269 \pm 0.031$ & $<0.001$ & 0.71 & $2.22 \pm 0.29$ \\
\hline \multicolumn{7}{|l|}{ Tibia mineralization } \\
\hline Weight & 0.838 & $0.033 \pm 0.004$ & $0.070 \pm 0.008$ & $<0.001$ & 0.70 & $2.12 \pm 0.31$ \\
\hline Length & 5.242 & $0.070 \pm 0.009$ & $0.130 \pm 0.019$ & $<0.001$ & 0.64 & $1.86 \pm 0.29$ \\
\hline Ash weight & 0.267 & $0.018 \pm 0.002$ & $0.039 \pm 0.004$ & $<0.001$ & 0.79 & $2.17 \pm 0.23$ \\
\hline Ash percentage & 31.847 & $0.594 \pm 0.083$ & $1.263 \pm 0.171$ & $<0.001$ & 0.65 & $2.13 \pm 0.32$ \\
\hline Ca percentage & 11.216 & $0.187 \pm 0.027$ & $0.472 \pm 0.056$ & $<0.001$ & 0.68 & $2.52 \pm 0.40$ \\
\hline$P$ percentage & 5.876 & $0.085 \pm 0.017$ & $0.214 \pm 0.034$ & $<0.001$ & 0.53 & $2.52 \pm 0.59$ \\
\hline \multicolumn{7}{|c|}{ Metatarsus mineralization } \\
\hline Weight & 0.632 & $0.020 \pm 0.003$ & $0.041 \pm 0.006$ & $<0.001$ & 0.59 & $2.05 \pm 0.37$ \\
\hline Length & 3.919 & $0.046 \pm 0.007$ & $0.087 \pm 0.014$ & $<0.001$ & 0.59 & $1.89 \pm 0.34$ \\
\hline Ash weight & 0.175 & $0.010 \pm 0.001$ & $0.020 \pm 0.002$ & $<0.001$ & 0.71 & $2.00 \pm 0.27$ \\
\hline Ash percentage & 26.868 & $0.570 \pm 0.073$ & $1.004 \pm 0.152$ & $<0.001$ & 0.65 & $1.76 \pm 0.26$ \\
\hline Ca percentage & 9.767 & $0.202 \pm 0.027$ & $0.350 \pm 0.057$ & $<0.001$ & 0.62 & $1.73 \pm 0.24$ \\
\hline$P$ percentage & 4.733 & $0.113 \pm 0.016$ & $0.187 \pm 0.033$ & $<0.001$ & 0.60 & $1.65 \pm 0.27$ \\
\hline
\end{tabular}


and Waldroup, 2003). These data indicate that the 25-OH$\mathrm{D}_{3}$ or vitamin $\mathrm{D}_{3}$ level should not exceed their requirement when evaluating the RBV of $25-\mathrm{OH}-\mathrm{D}_{3}$ to vitamin $\mathrm{D}_{3}$.

The optimal level of $25-\mathrm{OH}-\mathrm{D}_{3}$ was $10 \mu \mathrm{g} / \mathrm{kg}$ for promoting bone ash in broiler chicken diets (Goodgame et al., 2011). Thus, the level of $25-\mathrm{OH}-\mathrm{D}_{3}$ ranged from 1.25 to $10 \mu \mathrm{g} / \mathrm{kg}$ in the present study. No significant differences were observed in the tibia ash, breaking-strength, and the contents of $\mathrm{Ca}$ and $\mathrm{P}$ among the broilers fed with vitamin $\mathrm{D}_{3}$ ranging from 25 to $1,000 \mu \mathrm{g} / \mathrm{kg}$ (Han et al., 2013). Therefore, vitamin $\mathrm{D}_{3}$ levels were lower than those of our previous research (Han et al., 2013) and were at 2.5, 5, 10, and $20 \mu \mathrm{g} / \mathrm{kg}$ in the present study. Our results revealed the linear relationship between the $25-\mathrm{OH}-\mathrm{D}_{3}$ or vitamin $\mathrm{D}_{3}$ level and the performance or bone mineralization in broiler chickens.

The positive effects of $25-\mathrm{OH}-\mathrm{D}_{3}$ or vitamin $\mathrm{D}_{3}$ on growth performance and tibia weight, breaking-strength, and the percentage of ash, $\mathrm{Ca}$, and $\mathrm{P}$ in broiler chickens have been observed (Fritts and Waldroup, 2003; Rao et al., 2006; Han et al., 2012). The improvement of vitamin D derivatives on performance and bone of birds was caused by the increase of $\mathrm{Ca}$ and $\mathrm{P}$ utilization. Research has shown that addition of vitamin $\mathrm{D}_{3}$ (Qian et al., 1997), 25-OH- $\mathrm{D}_{3}$ (Ledwaba and Roberson, 2003), $1 \alpha-\mathrm{OH}-\mathrm{D}_{3}$ (Shirley, 2003; Han et al., 2012), or 1,25-(OH) $)_{2}-\mathrm{D}_{3}$ (Edwards, 2002) improves the retention of $\mathrm{Ca}$ and $\mathrm{P}$ in broiler chicken diets.

Previous research has shown that when bone ash was used as criteria, the RBV of $25-\mathrm{OH}-\mathrm{D}_{3}$ to vitamin $\mathrm{D}_{3}$ ranged from 1.0 to 2.5 (Soares et al., 1995). The RBV was from 1.11 to 1.38 in broiler breeder hens (Atencio et al., 2005). The present study showed that the RBV of $25-\mathrm{OH}-\mathrm{D}_{3}$ to vitamin $\mathrm{D}_{3}$ is approximately 2.03 for promoting growth performance and bone mineralization in 1- to 21-d-old broiler chickens. The differences in RBV values among the criteria were observed. Tibia gave the highest RBV of 25$\mathrm{OH}-\mathrm{D}_{3}$ to vitamin $\mathrm{D}_{3}(2.22)$ and followed by femur (2.07). The BWG and metatarsus criteria yielded the lowest values (1.85).

\section{CONCLUSIONS}

The present study indicates that the average RBV of 25$\mathrm{OH}-\mathrm{D}_{3}$ to vitamin $\mathrm{D}_{3}$ is approximately 2.03 (namely 203\%) for promoting growth performance and bone mineralization in 1- to 21-d-old broiler chickens fed with $\mathrm{Ca}$ - and Pdeficient diets.

\section{CONFLICT OF INTEREST}

We certify that there is no conflict of interest with any financial organization regarding the material discussed in the manuscript.

\section{ACKNOWLEDGMENTS}

This study was supported by the National Natural Science Foundation of China (31101732), the Innovation Scientists and Technicians Troop Construction Projects of Henan Province, the Foundation of the Education Department of Henan Province (16A230003), and the Shangqiu Normal University Foundation (2013GGJS10).

\section{REFERENCES}

Aburto, A., H. M. Edwards Jr., and W. M. Britton. 1998. The influence of vitamin A on the utilization and amelioration of toxicity of cholecalciferol, 25-hydroxycholecalciferol, and 1,25 dihydroxycholecalciferol in young broiler chickens. Poult. Sci. 77:585-593.

Applegate, T. J. and M. S. Lilburn. 2002. Growth of the femur and tibia of a commercial broiler line. Poult. Sci. 81:1289-1294.

Atencio, A., G. M. Pesti, and H. M. Edwards. Jr. 2005. Twenty-five hydroxycholecalciferol as a cholecalciferol substitute in broiler breeder hen diets and its effect on the performance and general health of the progeny. Poult. Sci. 84:1277-1285.

Baker, D. H., R. R. Biehl, and J. L. Emmert. 1998. Vitamin $\mathrm{D}_{3}$ requirement of young chicks receiving diets varying in calcium and available phosphorus. Br. Poult. Sci. 39:413-417.

Bar, A., D. Shinder, S. Yosefi, E. Vax, and I. Plavnik. 2003. Metabolism and requirements for calcium and phosphorus in the fast-growing chicken as affected by age. Br. J. Nutr. 89:5160.

Biehl, R. R. and D. H. Baker. 1997. Utilization of phytate and nonphytate phosphorus in chicks as affected by source and amount of vitamin $D_{3}$. J. Anim. Sci. 75:2986-2993.

Edwards Jr., H. M. 2002. Studies on the efficacy of cholecalciferol and derivatives for stimulating phytate utilization in broilers. Poult. Sci. 81:1026-1031.

Fritts, C. A. and P. W. Waldroup. 2003. Effect of source and level of vitamin $\mathrm{D}$ on live performance and bone development in growing broilers. J. Appl. Poult. Res. 12:45-52.

Goetting-Fuchs, C., R. Günther, V. G. Liesner, B. G. Liesner, M. Beyerbach, and J. Kamphues. 2012. Investigations on skeletal development, bone mineralisation as well as calcium and phosphorus levels in blood of male fattening turkeys. Europ. Poult. Sci. 76:121-130.

Goodgame, S. D., F. J. Mussini, C. Lu, C. D. Bradley, S. E. Watkins, and P. W. Waldroup. 2011. Evaluation of a fermentation source of 25-hydroxycholecalciferol in broiler diets. Int. J. Poult. Sci. 10:295-299.

Hall, L. E., R. B. Shirley, R. I. Bakalli, S. E. Aggrey, G. M. Pesti, and H. M. Edwards. Jr. 2003. Power of two methods for the estimation of bone ash of broilers. Poult. Sci. 82:414-418.

Han, J. C., H. X. Qu, J. G. Wang, G. H. Chen, Y. F. Yan, J. L. Zhang, F. M. Hu, L. Y. You, and Y. H. Cheng. 2015. Comparison of the growth and mineralization of the femur, tibia, and metatarsus of broiler chicks. Braz. J. Poult. Sci. 17:333-339.

Han, J. C., H. X. Qu, J. Q. Wang, J. H. Yao, C. M. Zhang, G. L. Yang, Y. H. Cheng, and X. S. Dong. 2013. The effects of 
dietary cholecalciferol and $1 \alpha$-hydroxycholecalciferol levels in a calcium- and phosphorus-deficient diet on growth performance and tibia quality of growing broilers. J. Anim. Feed Sci. 22:158-164.

Han, J. C., Y. Liu, J. H. Yao, J. Q. Wang, H. X. Qu, Y. F. Yan, J. Yue, J. L. Ding, Z. T. Shi, and X. S. Dong. 2012. Dietary calcium levels reduce the efficacy of one alphahydroxycholecalciferol in phosphorus-deficient diets of broilers. J. Poult. Sci. 49:34-38.

Jendral, M. J., D. R. Korver, J. S. Church, and J. J. R. Feddes. 2008. Bone mineral density and breaking strength of white leghorns housed in conventional, modified, and commercially available colony battery cages. Poult. Sci. 87:828-837.

Koreleski, J. and S. Swiatkiewicz. 2005. Efficacy of different limestone particle size and 25-hydroxycholecalciferol in broiler diets. J. Anim. Feed Sci. 14:705-714.

Ledwaba, M. F. and K. D. Roberson. 2003. Effectiveness of twenty five hydroxycholecalciferol in the prevention of tibial dyschondroplasia in Ross cockerels depends on dietary calcium level. Poult. Sci. 82:1769-1777.

Littell, R. C., P. R. Henry, A. J. Lewis, and C. B. Ammerman. 1997. Estimation of relative bioavailability of nutrients using SAS procedures. J. Anim. Sci. 75:2672-2683.

Qian, H., E. T. Kornegay, and D. M. Denbow. 1997. Utilization of phytate phosphorus and calcium as influenced by microbial phytase, cholecalciferol, and the calcium: Total phosphorus ratio in broiler diets. Poult. Sci. 76:37-46.
Rao, S. V. R., M. V. L. N. Raju, A. K. Panda, G. S. Sunder, and R. P. Sharma. 2006. Effect of high concentrations of cholecalciferol on growth, bone mineralization, and mineral retention in broiler chicks fed suboptimal concentrations of calcium and nonphytate phosphorus. J. Appl. Poult. Res. 15:493-501.

Rao, S. V. R., M. V. L. N. Raju, A. K. Panda, G. S. Sunder, and R. P. Sharma. 2009. Performance and bone mineralisation in broiler chicks fed on diets with different concentrations of cholecalciferol at a constant ratio of calcium to non-phytate phosphorus. Br. Poult. Sci. 50:528-535.

Rao, S. V. R., M. V. L. N. Raju, and M. R. Reddy. 2007. Performance of broiler chicks fed high levels of cholecalciferol in diets containing sub-optimal levels of calcium and nonphytate phosphorus. Anim. Feed Sci. Tech. 134:77-88.

SAS Institute. 2002. SAS User's Guide. 9th edn. SAS Inst. Inc., Cary, NC, USA.

Shirley, R. B. 2003. Evaluation of Phytase, Vitamin $D_{3}$ Derivatives, and Broiler Breed Differences on Nutrient Utilization, Broiler Performance, Leg Disorders, and the Expression of Intestinal Calbindin-28 kd mRNA and Protein. Ph.D. Dissertation. University of Georgia, Athens, GA, USA.

Soares Jr., J. H., J. M. Kerr, and R. W. Gray. 1995. 25hydroxycholecalciferol in poultry nutrition. Poult. Sci. 74:1919-1934.

Yarger, J. G., C. A. Saunders, J. L. McNaughton, C. L. Quarles, B. W. Hollis, and R. W. Gray. 1995. Comparison of dietary 25hydroxycholecalciferol and cholecalciferol in broiler chickens. Poult. Sci. 74:1159-1167. 